5. Tolkovyi slovär kazahskogo iazyka. Toma I-X. [Explanatory dictionary of Kazakh language. Volumes I-X]-Almaty: Nauka, 1974-1986. (na kazahskom iazyke, slovär)

6. Anglo-ruskih diplomaticheskih slovarei. [Anglo-Russian diplomatic dictionaries.] -M.: Ruski iazyk, 2001. -855 s. (slovär)

7. Vilüman V. G. Angliskaia sinonimia.[English synonymy]-M.: Vysşaia şkola, 1980. -128 s.)

8. Vasilev L. M. Sovremennaia lingvisticheskaia semantika iazyka. [Modern linguistic semantics of language.] -M.: Vyşşaia şkola, 1990. -175 s.)

9. Novikov L. A. Entoni na ruskom iazyke. [Anthony in Russian. ]-M., 1973. -161 s. (na ruskom iazyke, kniga)

10. Isanova A.Sh Iuridicheskie terminy $v$ sovremennom kazahskom literaturnom iazyke: kand.filol.nauk. kandidatskaia disertasia.[Legal terms in the modern Kazakh literary language: cand.philol. sciences' thesis.] -Almaty, 1997. -S. 6.(na kazahskom iazyke, disertasia)

11.İsserlin E. M. Leksika i frazeologia sovremennyh diplomaticheskih dokumentov. [Vocabulary and phraseology of modern diplomatic documents. ]-M., 1966. -S. 15)

МРНТИ 16.21.35

https://doi.org/10.51889/2020-2.1728-7804.24

\author{
Kartbayeva D., ${ }^{1}$ Zhambylkyzy $M .{ }^{2}$ \\ 1,2 al Farabi KazNU, \\ Almaty, Kazakhstan
}

\title{
DERIVATION AND FORMATION FEATURES OF PHARMACOLOGICAL TERMINOLOGY IN RUSSIAN AND ENGLISH LANGUAGES
}

Abstract
This article is devoted to the Derivation and formation features of pharmacological terminology. Pharmacological terminology is one of the specific strata of vocabulary that occupies a special place in the language system, which is explained by its structural-semantic, word-formation and stylistic features. In recent decades, there has been an acceleration in the process of internationalization of pharmacological terminology. The source of internationalization in the terminological system of medicine is the morphemes of classical languages such as Latin and Greek; previously borrowed general literary words and then terminologically rethought and borrowing finished terminological units. For the vast majority of European languages, this source is mainly English pharmacological terminology and contain approximately more than 10000 terms.

Keywords: Pharmacological, terminology, formation, derivation, Latin, English, Russian, internalization, scientific, comparative. Lexico-semantic, features

\author{
Картбаева Д., ${ }^{1}$ Жамбылқызы . $^{2}$ \\ 1,2 әл-Фараби атындавы Қазақ ұлттық университеті, \\ Алматы, Қазақстан
}

\section{ФАРМАКОЛОГИЯЛЫҚ ТЕРМИНОЛОГИЯНЫН АҒЫЛШЫН ЖӘНЕ ОРЫС ТІЛДЕРІНДЕ ТУЫНДЫСЫ ЖӘНЕ ҚҰРЫЛУЫНЫҢ ЕРЕКШЕЛІКТЕРІ}

\section{Аң̧датпа}

Бұл мақала фармакологиялық терминологияның ерекшеліктерін тұжырымдау мен қалыптастыруға арналған. Фармакологиялық терминология - тілдік жүйеде ерекше орын алатын, оның құрылымдық-семантикалық, туынды және стилистикалық ерекшеліктерімен түсіндірілетін лексиканың ерекше қабаттарының бірі. Соңғы онжылдықта фармакологиялық терминологияны интернационализациялау процесінде жеделдеу байқалды. Медицинаның терминологиялық жүйесіндегі интернационализацияның қайнар көзі - латын және грек сияқты классикалық тілдердің морфемалары; бұрын жалпы әдеби сөздерді, содан кейін терминологиялық тұрғыдан қайта 
ойластырып, толық терминологиялық бірліктерді қарызға алды. Еуропалық тілдердің басым көпшілігі үшін бұл дереккөз негізінен ағылшын фармакологиялық терминологиясы болып табылады және шамамен 10000 терминді қамтиды.

Түйін сөздер: фармакология, терминология, білім, туынды, латын, ағылшын, орыс, интернационализация, ғылыми, салыстырмалы. Лексикалық және семантикалық ерекшеліктері

\author{
Картбаева Д., ${ }^{1}$ Жамбылқызы М. $^{2}$ \\ ${ }^{1,2}$ КазНУ им. аль-Фараби, \\ Алматы, Казахстан
}

\title{
ОСОБЕННОСТИ ПРОИСХОЖДЕНИЯ И ФОРМИРОВАНИЯ ФАРМАКОЛОГИЧЕСКОЙ ТЕРМИНОЛОГИИВ АНГЛИЙСКОМ И РУССКОМ ЯЗЫКАХ
}

Аннотация

Данная статья посвящена происхождению и формированию особенностей фармакологической терминологии. Фармакологическая терминология является одним из специфических слоев словарного запаса, занимающим особое место в языковой системе, что объясняется ее структурносемантическими, словообразовательными и стилистическими особенностями. В последние десятилетия наблюдается ускорение процесса интернационализации фармакологической терминологии. Источником интернационализации в терминологической системе медицины являются морфемы классических языков, таких как латинский и греческий; ранее заимствованные общие литературные слова, а затем терминологически переосмысление и заимствование законченных терминологических единиц. Для подавляющего большинства европейских языков этот источник является в основном английской фармакологической терминологией и содержит приблизительно более 10000 терминов.

Ключевые слова: фармакология, терминология, образование, деривация, латынь, английский, русский, интернализация, научная, сравнительная. Лексико-семантические особенности

Introduction. As we are living in the era of globalization, integration and market relations nobody can doubt the significance of terminology in our life as it integrates obscure data of a specific field into one explicit term and aids in mastering people's professional education. Thus, any field of science and technology finds its expression in terms and there is practically no field of education that could be studied without knowledge of the terminology.

Pharmacological terminology is one of the specific strata of vocabulary, which, due to structural, semantic, word-formation and stylistic features, differs from commonly used words and, therefore, occupies a special place in the lexical system of the language. The analysis of hierarchical structural relations in a single lexico-semantic group of pharmacological terminology makes it possible to reveal not only systemic relations in the vocabulary of the Russian, Latin and English languages, but also to identify the identity and differences in lexical-semantic phenomena in comparative languages, which is important for comparatively typological, and for descriptive studies.

The inexhaustibility of the problems of this lexical stratum attracts linguists - researchers today to the discovery of its new qualities, sides, characteristics, features as a subsystem of the language.

The subject of my study is pharmacological terminology in Russian and English derived from Latin, based on the fact that these parallel subsystems were not subjected to special study.

The object of our study is to identify ways of transmitting the meanings of Latin pharmacological terms into English and Russian.

The purpose of the dissertation research is to reflect the essence of such a complex and multifaceted concept as the term and systematic study of semantic and structural-derivational features of the formation of the pharmacological terminology of the Russian and English languages.The following research objectives come from here:

- supplement the definition of the essence of the term, give an explanation of its main characteristics;

- determine the place of pharmacological terminology in the lexical systems of the Russian and English languages; 
- identify lexical and semantic features of pharmacological terminology as a special layer of lexical systems in Latin and English;

- describe the features of the etymology of pharmacological terms on the material of the Russian and English languages;

- characterize the role of Latin terminological elements in pharmacological terminology;

- to analyze the pharmacological terminology of the compared languages in relation to internationalization, systematicity and unification;

- study the features of the translation of pharmacological terms.

Methodology.The choice of English as the second language of comparative research is determined by its ever-increasing communicative role in the world community, popularity, and today's vital necessity.

It should be noted that a comparative study of multisystem contact languages on the material of a certain terminological subsystem is especially important for objective forecasting of the development and functioning of the considered language terminologies and the successful solution of theoretical and applied problems in coordinating them with each other.

Moreover, It should be mentioned that at the present stage, pharmacological terms are widely used in colloquial speech, in a literary language, in the field of healthcare, pharmacological activity and science. However, the use of pharmacological terms in Russian has not yet been the subject of a serious and profound study. Further development of pharmacological terminology requires appropriate research and streamlining.

Therefore, pharmacological terminology is analyzed within the framework of the system into which it naturally enters, that is, as part of the vocabulary of the language of science. Terminology does not belong to any other lexical system and cannot belong. The terminology has its own special purpose, the implementation of which is possible only in the language of science. The terms refer to special concepts that arise not in everyday life, but in the corresponding fields of scientific and practical activity. The belonging of the terms to the lexical system of the language of science is determined not only functionally, but also by the fact that they are signs of a different semiotic nature, the basis of which is "the one-to-one correspondence of the sign and the signified", and which "regulates the properties of a language sign, making it a term".

Despite the considerable amount of work available in both domestic and foreign literature, the linguistic aspect of the study of terminological vocabulary still needs in-depth studies.

Pharmacological terminology is a layer of the lexical fund with its specific features, because in every professional sublanguage there is nomenclature vocabulary that is correlated with certain realities and objects. The peculiarity of the vocabulary of the terminology is that its nouns are represented in it wider, more diverse than in other lexical subsystems.

The terminology takes place in two areas (within the language of science, implemented in specific genre-diverse texts): in the field of fixation (lexicographic genres: special dictionaries, collections of recommended terms) and c. sphere of functioning (special literature: articles, monographs, periodicals).

That is why the source of the study of the structural-word-forming organization of pharmacological terms in modern Russian and English languages was the materials of pharmacological terminology, collected from specialized dictionaries, literary works, which provide examples of the features of the practical use of terms in vocabulary.

The main methods of studying the laws of pharmacological terminology were a systematic, contrastive, comparative study of pharmacological terminology, the descriptive method and the method of component analysis of the word-forming organization of pharmacological vocabulary are used.

Results.Pharmacological terminology is one of the microsystems that is the part of the vocabulary of modern English and Russian languages. This microsystem has, on the one hand, the features inherent in the general literary language, and on the other hand, it has its own distinct specificity. The data obtained as a result of studying pharmacological terminology problems, such as characterization of the essence of such a complex and multifaceted concept as a term and systematic study of semantic and structurally derivational features of the pharmacological terminology of the Russian and English languages, analysis of the main methods of term formation, use of Latin and Greek terminological elements, study of the etymology of pharmacological terms, a description of the characteristic aspects of pharmacological oh terminology, such as internationalization, consistency and standardization of pharmaceutical terminology, description of the synonym problem in the pharmaceutical terminology, translation features and pharmacological terms termino-elements have great theoretical and practical importance for the translation of specialized texts from English, as well as for the study of the language itself. At the same time, data obtained in 
The process of term formation, studied on the basis of pharmacological terminology, reflects the level of development of the corresponding fields of knowledge.

The most common and typical features of terminological word formation are the following:

1) the terms are created only for the needs of special communication;

2) term-creation - a conscious process, not spontaneous;

3) terminology - a controlled and regulated process;

4) the word-formation act in terminology presupposes, besides the derivative operation itself, verbal disclosure of the terminology's content, within the framework of • pharmacological terminology, this is the name of the disease, drug, anatomical or histological nomenclature, etc .;

5) the medical term is characterized by a transparent internal form;

6) a specific act of terminological word formation depends on the classification of concepts.

Modern pharmacological terminology in comparative languages is based on the Latin - Greek and Arabic basis.

A huge mass of Latin words in all ages has been a source of enrichment of the scientific vocabulary of Europe and the whole world. These words are usually international in nature. I

Despite some differences in the pronunciation of these words in different languages, they are nevertheless clear to physicians without translation. But in Latin, they differ in spelling and sound and yet express the same meaning in comparative languages. Russian used Arabic terms along with Latin and Greek.

Discussion.Modern pharmacological terminology is heterogeneous in origin.

Along with the native Russian and English words, which make up a small amount of $8 \%$, there are terms of Greek and Latin origin $71 \%$ that have become international, the other $21 \%$ came from the Arabic language.

In recent decades, there has been an acceleration in the process of internationalization of pharmacological terminology. The source of internationalization in the terminological system of medicine is the morphemes of classical languages such as Latin and Greek; previously borrowed general literary words and then terminologically rethought and borrowing finished terminological units. For the vast majority of European languages, this source is mainly English pharmacological terminology. Synonymy embraces the special vocabulary of the language of science as an ongoing process, the most active in the initial stages of the formation of industry terminologies, when the natural selection of terms is in progress.

Pharmacological terminology is no exception in this case. In pharmacological terminology, first of all, a semantic variety of synonymy with its characteristic functions of substitution and refinement is realized.

Although there are a large number of works covering the main problems of terminology, there are many aspects that require special attention of researchers. Such are the experiments of a comparative 'typological analysis of individual terminological systems in various languages.

Pharmacological terminology is one of the specific strata of vocabulary that occupies a special place in the language system, which is explained by its structural-semantic, word-formation and stylistic features.

An analysis of hierarchical structural relations in a single lexico-semantic group of pharmacological terminology makes it possible not only to reveal systemic relations in the vocabulary of the Russian and English languages, but also the systemic relations of identities and differences of lexical-semantic phenomena in comparative languages, which is very important for comparatively typological so for descriptive studies.

The common arsenal of Greek - Latin internationalisms, both words and terminological elements in both languages (Latin and English) creates a solid base for terminological understanding.

In the pharmacological terminology of comparative languages, synonyms occupy a significant place. Given the "synonymous hypertrophy", the most optimal is the selection of only the most viable, with sufficient practical use of Russian synonyms, with which equally viable English synonyms harmonize.

In both Russian and English, the anatomical names have their own linguistic origin: Болеутоляющееanalgetic, жаропонижающее- antipyretic, противомикробное - antimicrobial etc.

When studying pharmacological terminology, one must take into account that knowledge is systemic in nature. The systemic nature of scientific knowledge is reflected in the system of concepts.

Conclusion.Thus, it can be concluded that in order to master any language and achieve qualified professional communication, it is necessary to do a lot of work in the field of semantics, both on the basis of different styles of one language and one style of different languages. 
A characteristic feature of the modern terminological system of pharmacology is the expansion of its international layer as a result of the interaction and mutual enrichment of various languages and the need for international communication.

As a result of the study of such problems of terminology as the ways and methods of term formation, that is, the semantic and structurally word-formation organization of terms in modern Latin and English, contribute to the development and streamlining of individual terminological systems. Summing up the study of the essence of the term and the place of pharmacological terminology in the vocabulary of the Russian and English languages, we can say that pharmacological terminology is used in its direct, nominative-definitive function only \& the composition of the language of science. The penetration of certain terms into general literary vocabulary is evidence of their popularity, prevalence, use in various genres of literature, and, finally, the development of these terms in the literary language, but not in general terms of the terms generally in the general literary language.

\section{References}

1. Dzuganova B. Kratki ocherk razvitia medisinskogo angliskogo iazykall Bratislavski lektori. [A brief outline of the development of medical English// BratislLekListy. ] Tom 103(6).2012.-s. 223-227.

2. Mochenko,V. V. Osnovnye tendensii formirovania angliskoi medisinskoi terminologii.-M.: [Maintendenciesin formation of English medical terminology.-Moscow] Moskovski pedagogicheski universitet, 2001.

3. 3 Buialkova. Juganova B. Angliskie i latinskie korpusa medisinskih terminov - sravnitelnoe issledovanie// Mejdunarodnyi jurnal gumanitarnyh i sosiälnyh nauk, tom 2. [English and Latin Corpora of Medical Terms - A Comparative Study// International Journal of Humanities and Social Sciences Vol 2] 2015.- S. 82-91

4. Beran A. A pragmatic and empirical approach to Medical terminology Instruction From Latin grammar to Professional Language Learning //International Journal for Humanities and Natural Sciences vol 6-3.2019.-P. 7-8

5. Abduraşidova H. B., Orehin-Ryjina V. A. Vlianie fransuzskih terminov, zaimstvovannyh iz latinskogo iazyka, na razvitie medisinskoi terminologii//Älmanah molodoi nauki, [Theinfluence of French terms borrowed from Latin language to the development of medical terminology//Almanac of Young science ] 2015.-S. 17-21.

6. Mareskova E, Simon F, Cherveni L. Lätyn kak iazyk medisinskoi terminologii: nekotorye zamechania o ee roli $i$ perspektivah// Şveisarskaia medisina. [Latin as the language of medical terminology: some remarks on its role and prospects// Swiss Med Wkly.] 2002.-s. 581-587.

МРНТИ 16.41.09

\author{
Карагулова Б. ${ }^{l}$ \\ ${ }^{1}$ Қ. Жұбанов атындагы Ақ̧төбе өңірлік мемлекеттік университеті, \\ Ақ̧төбе, Қазақстан
}

\section{ТУРКІ ТІЛДЕРІНЕ ТӘН ЗАТТЫҚ - МӘДЕНИ АТАУЛАРДЫҢ ЭВОЛЮЦИЯСЫ}

\section{Аңџдатпа}

Тіл - мәдениеттің бір көрінісі. Ол екеуінің байланысы ерекше де маңызды. Кез келген мәдениеттің түрлері, атаулары тіл арқылы бейнеленіп көрінетіні, ұрпақтан-ұрпаққа жеткізілетіні белгілі. Ұлттың пайда болуы мен бірге тілдік, шаруашылық аймақтық тұтастықтар болуы мен бірге тілдік, шаруашылық аймақтық тұтастықтар секілді, психикалықтұтастықтардың қалыптасуымен байланысты. Сондықтан түркі тілдеріне тін атаулардың арасындағы ұқсатық пен айырмашылықты анықтау - тіл білімінің негізгі проблемалардың бірі болып табылады.сөз эволюциясының үнемі өзгеріске түсіп, даму үстінде болатындығы баршамызға белгілі. Ал осы даму тілдегі сөздердің қолданысына, олардың мағыналарына өзгеріс әкелері сөзсіз.

Аталған мақалада түркі тілдеріне тән заттық мәдени атаулар және оның мағыналық, формалық айырмашылықтры тілдік- тарихи деректер арқылы анықталып, зерттеледі. Қазіргі қазақ тілінде тілдің 